\title{
Trafficking of the microdomain scaffolding protein reggie-1/flotillin-2
}

\author{
Matthias F. Langhorst*, Alexander Reuter, Friederike A. Jaeger ${ }^{1}$, Frank M. Wippich ${ }^{1}$, \\ Georg Luxenhofer ${ }^{2}$, Helmut Plattner ${ }^{3}$, Claudia A.O. Stuermer ${ }^{3}$ \\ Department of Biology, University of Konstanz, Universitätsstraße 10, D-78457 Konstanz, Germany
}

\begin{abstract}
The reggie/flotillin proteins oligomerize and associate into clusters which form scaffolds for membrane microdomains. Besides their localization at the plasma membrane, the reggies/flotillins reside at various intracellular compartments; however, the trafficking pathways used by reggie-1/flotillin-2 remain unclear. Here, we show that trafficking of reggie-1/flotillin-2 is BFA sensitive and that deletion mutants of reggie-1/flotillin-2 accumulate in the Golgi complex in HeLa, Jurkat and PC12 cells, suggesting Golgi-dependent trafficking of reggie-1/flotillin-2. Using total internal reflection fluorescence microscopy, we observed fast cycling of reggie-1/flotillin-2-positive vesicles at the plasma membrane, which engaged in transient interactions with the plasma membrane only. Reggie-1/flotillin- 2 cycling was independent of clathrin, but was inhibited by cholesterol depletion and microtubule disruption. Cycling of reggie1/flotillin-2 was negatively correlated with cell-cell contact formation but was stimulated by serum, epidermal growth factor and by cholesterol loading mediated by low density lipoproteins. However, reggie-1/flotillin-2 was neither involved in endocytosis of the epidermal growth factor itself nor in endocytosis of GPI-GFPs or the GPI-anchored cellular prion protein $\left(\operatorname{PrP}^{\mathrm{c}}\right)$. Reggie-2/flotillin-1 and stomatin-1 also exhibited cycling at the plasma membrane similar to reggie-1/flotillin-2, but these vesicles and microdomains only partially co-localized with reggie-2/flotillin-1. Thus, regulated vesicular cvcling might be a general feature of SPFH protein-dependent trafficking.
\end{abstract}

Keywords: Reggie/flotillin; Membrane trafficking; TIRF microscopy; Endocytosis; Endocytic cycling; Prion protein

\section{Introduction}

Reggie-1 and reggie-2 were discovered in our lab as proteins upregulated during axon regeneration after optic nerve lesion (Schulte et al., 1997; Lang et al., 1998). They

\footnotetext{
${ }^{*}$ Corresponding author. Carl Zeiss MicroImaging GmbH, Königsallee 9-21, D-37081 Göttingen, Germany.

E-mail address: Matthiaslanghorst@email.de (M.F. Langhorst).

${ }^{1}$ These authors contributed equally.

${ }^{2}$ Present address: Institute of Physiology, University of Hohenheim, Garbenstraße 30, D-70593 Stuttgart, Germany.

${ }^{3}$ These authors contributed equally.
}

were independently described as proteins abundant in the floating, detergent-resistant membrane fraction prepared from murine lung tissue and therefore named flotillin-2 and -1 , respectively (Bickel et al., 1997). The reggies/ flotillins consist of an N-terminal SPFH domain containing residues for myristoylation and palmitoylation and thus membrane anchorage (Neumann-Giesen et al., 2004), and a C-terminal flotillin domain which is predicted to form coiled-coil structures (Schroeder et al., 1994; Bickel et al., 1997; Schulte et al., 1997). Via this domain, the reggies/flotillins form homo- and hetero-oligomers (Neumann-Giesen et al., 2004; Solis et al., 2007), which 
assemble into clusters of $50-100 \mathrm{~nm}$ at the plasma membrane (Stuermer et al., 2001). These clusters define specialized flat membrane microdomains and serve as stable scaffolds for the assembly of multiprotein complexes, similar to caveolin clusters in caveolae (reviewed in Langhorst et al. (2005)). Reggie/ flotillin-dependent signaling complexes were shown to be involved in actin remodeling during $\mathrm{T}$ cell activation (Langhorst et al., 2006b) and in Glut4translocation to the plasma membrane after insulin stimulation of adipocytes (Baumann et al., 2000; Kimura et al., 2001).

The biosynthetic pathway of the reggies/flotillins is controversial. Reggie-2/flotillin-1 was found to travel through the Golgi in NRK, $\mathrm{CHO}$ and HeLa cells (Gkantiragas et al., 2001). However, Morrow et al. (2002) observed Sar1- and Brefeldin A (BFA)-independent trafficking of reggie-2/flotillin-1 in BHK cells, suggesting a Golgi-independent pathway. In addition to their prominent localization at the plasma membrane, both reggies/flotillins reside at intracellular compartments. They localize to lipid droplets (Liu et al., 2004; Reuter et al., 2004) and to compartments of the endocytic pathway, like recycling endosomes (Gagescu et al., 2000; Solomon et al., 2002). Reggie-2/flotillin-1 was recently implicated in an unconventional, clathrin- and caveolin-independent endocytosis pathway used by GPI-anchored proteins (Glebov et al., 2006) and proteogylcan-binding ligands (Payne et al., 2007).

In this study, we investigated the trafficking pathways of reggie-1/flotillin-2 and its role in endocytosis of GPIanchored proteins, especially the cellular prion protein $\operatorname{PrP}^{\mathrm{c}}$ in detail. We provide evidence for Golgi-dependent trafficking of reggie-1/flotillin-2. At the plasma membrane, reggie-1/flotillin-2 exhibited vesicular cycling, which was regulated by epidermal growth factor stimulation, cholesterol loading and cell-cell contact formation. Reggie-2/flotillin-1 and stomatin-1 vesicles showed similar behavior but distinct localizations, suggesting that regulated protein delivery and retrieval by vesicular cycling might be a general function of the membrane microdomain-forming proteins of the SPFH family.

\section{Material and methods}

\section{Antibodies, reagents and cells}

Anti-GM130, anti-reggie-1/flotillin-2, anti-reggie-2/ flotillin-1 monoclonal antibodies were purchased from BD Transduction Laboratories (Heidelberg, Germany), anti-HA monoclonal antibody from Roche (Mannheim, Germany), anti-PrP $\mathrm{P}^{\mathrm{c}}$ monoclonal (6H4) antibody from Prionics (Zurich, Switzerland), anti-EGFR polyclonal antibody from Cell Signalling (Beverly, USA).
Reggie/flotillin polyclonal antibodies were described previously (Stuermer et al., 2001). Secondary antibodies coupled to Cy3 were from Jackson ImmunoResearch (Soham, UK), secondary antibodies coupled to Alexa488 and lysotracker red DND-99 from Molecular Probes (Invitrogen, Karlsruhe, Germany). Brefeldin A, okadaic acid, FM4-64 and nocodazole were purchased from Calbiochem (Bad Soden, Germany), methyl- $\beta$ cyclodextrin from Sigma (Munich, Germany), LDL was from AppliChem (Darmstadt, Germany).

Deletion mutants were obtained by PCR using rat fulllength reggie-1 cloned in pEGFP-N1 or -C1 (Clontech, Heidelberg, Germany) as template (Neumann-Giesen et al., 2004) and primers introducing restriction sites for EcoRI and BamHI. Fragments were then subcloned into pEGFP-N1. As a kind gift, we obtained clathrinmRFP from K. Rottner (Helmholtz Centre for Infection Research, Braunschweig, Germany), GPICFP (DAF) from D. Legler (Biotechnology Institute Thurgau, Taegerwilen, Switzerland), EGFP-stomatin1 from D. Browman (University of Calgary, Canada), Eps15 and dynamin dominant-negative mutants from A. Benmerah (Cochin Institute, Paris, France) and GPI-EGFP (PrP) from G. Solis (University of Konstanz).

HeLa, PC12 and Jurkat T cells were cultured and transfected as described previously (Langhorst et al., 2006a, b). Reggie/flotillin localization depends on the expression level; therefore, we kept the expression level very low, the cells analyzed expressed reggie/flotillinEGFP at levels comparable to the endogenous protein, as verified by Western blotting (data not shown).

\section{Immunofluorescence and confocal microscopy}

Cells were transfected, fixed $24 \mathrm{~h}$ post-transfection with formaldehyde (freshly prepared from $4 \%$ paraformaldehyde), permeabilized with $0.1 \%$ Triton X-100 and stained with the appropriate combinations of primary and secondary antibodies and DAPI, before mounting in Mowiol. Alternatively, cells were fixed and permeabilized with methanol at $-20^{\circ} \mathrm{C}$. Confocal microscopy was carried out using an LSM 510 META and a $63 \times$ Plan-Apochromat $(\mathrm{NA}=1.4)$ objective (both Carl Zeiss, Jena, Germany) in 12-bit mode. Images were processed using the LSM 510 software and AxioVision 4.6 (Carl Zeiss).

\section{Electron microscopy}

For immunogold localization, cells were prepared essentially as described previously (Stuermer et al., 2001, 2004). Briefly, cells were fixed in $8 \%$ formaldehyde $+0.1 \%$ glutaraldehyde in phosphate-buffered saline (PBS, pH 7.4) for $1 \mathrm{~h}$ at $0{ }^{\circ} \mathrm{C}$, washed in $\mathrm{PBS}+50 \mathrm{mM}$ 
glycine and PBS alone. For cryo-sections, pelleted cells were stirred in $8 \%$ gelatin, centrifuged and impregnated overnight at $4{ }^{\circ} \mathrm{C}$ with $2.3 \mathrm{M}$ sucrose and $20 \%$ polyvinyl pyrrolidone, PVP10. Frozen cell pellets were cryosectioned. Cell sections were then incubated with primary antibodies followed by the specified goldconjugate (protein $\mathrm{A}$ or $\mathrm{F}(\mathrm{ab})_{2}$ fragments conjugated to 5 or $10 \mathrm{~nm}$ gold). Alternatively, we performed LR-gold embedding and UV polymerization at $-35^{\circ} \mathrm{C}$. Electron micrographs enlarged to $80,000 \times$ magnification were evaluated quantitatively as follows. Gold granules within the compartment to be analyzed were counted, including a marginal zone of $15 \mathrm{~nm}$ (size of an antibody-gold conjugate complex). For complex organelles (dictyosomes and Golgi vesicles), values were determined for an area within the circumference of the respective zone to be analyzed. The number of gold granules counted was referred to the area size of a given organelle as described previously (Plattner and Zingsheim, 1983). The labeling density within an organelle was compared to nearby cytosolic domains. Thus, the "enrichment factors" $( \pm$ S.D.M.) given in the text represent the enrichment of label in a specific organelle with reference to the nearby cytosol.

\section{TIRF imaging and analysis of membrane-near trafficking}

Total internal reflection microscopy was carried out on an Axiovert 200M using the TIRF slider system, a $100 \times \alpha$-Plan-Fluar $(\mathrm{NA}=1.45)$ objective and an AxioCam MR rev3 (all Carl Zeiss) operated at binning 2 and a frame rate of 3 frames/s. Cells were kept in medium 199 (Invitrogen) with or without 10\% fetal calf serum or other stimuli. For quantitative analysis of membrane-near trafficking, we adapted a method published previously (Pelkmans and Zerial, 2005) using Image J (Abramoff et al., 2004) for sequence processing. We subtracted the first frame of a sequence from the maximum intensity projection of all subsequent frames. We then applied an automatic thresholding based on the background outside the cell with a scaling factor of $5-10$. In the resulting binary image, only those pixels were black where the intensity had significantly changed during the sequence, thus representing trafficking events. We measured the area of these pixels and the number of trafficking events using the particle counter function of ImageJ. Both values were always correlated, indicating that lateral mobility as well as number of vesicles in the evanescent field were always similarly affected by the various treatments. We then measured the footprint area of the cell and calculated the ratio of active pixels per total cell area $(\Delta F /$ cell area) in percent as a quantitative value for trafficking activity ("trafficking density").

\section{Results}

\section{Reggie-1/flotillin-2 trafficking is Golgi dependent}

To elucidate the biosynthetic trafficking pathway of reggie-1/flotillin-2, we used deletion mutants lacking specific functional domains of the protein (Fig. 1A). C-terminal EGFP-tagging of the full-length reggie-1/ flotillin-2 protein does not significantly alter its biochemical properties and its subcellular localization (Neumann-Giesen et al., 2004; Langhorst et al., 2006b). Endogenous reggie-1/flotillin-2 (data not shown) and EGFP-tagged full-length reggie-1/flotillin-2 (R1FLEGFP) did not localize to the Golgi complex to any significant extent in HeLa cells at steady state (Fig. 1B). Deletion of the whole flotillin-domain (R1NT, Fig. 1C) did not significantly alter the localization of the protein. A deletion construct lacking the SPFH domain (R1MCT), however, accumulated in the Golgi complex as shown by co-localization with the Golgi marker GM130 (Fig. 1D). In addition, we observed the accumulation of many R1MCT-vesicles in the cytosol (Fig. 1D). The isolated membrane-anchoring domain of reggie-1/flotillin-2, consisting of the first 30 amino acids including the acylation sites, predominantly localized to the Golgi complex (Fig. 1E). Experiments carried out in Jurkat $\mathrm{T}$ and $\mathrm{PC} 12$ cells confirmed the localization of endogenous reggie-1/flotillin-2 and of all EGFP-tagged constructs (data not shown). This suggests that information for Golgi-transit must be encoded in the reggie-1/ flotillin-2 amino acid sequence.

To evaluate Golgi-dependent trafficking of reggie-1/ flotillin-2 at the ultrastructural level, we performed immunogold electron microscopy (EM). Reggie-1/flotillin-2 was localized to vesicles in the Golgi field (Fig. 2A) in Jurkat $\mathrm{T}$ cells, but not in Golgi stacks. This was substantiated by our quantitative evaluation showing a highly significant enrichment of gold grains in Golgi vesicles as opposed to Golgi stacks $(16.2 \pm 4.7$ vs. $0.9 \pm 0.5$, enrichment factors relative to surrounding cytoplasm, values pooled from 50 cell sections). The deletion mutant R1MCT, which showed accumulation in the Golgi in fluorescence microscopy was also localized to vesicles in the Golgi field in EM studies in HeLa cells (data not shown). Thus, reggie-1/flotillin-2 does not localize to Golgi stacks in steady state, but is clearly found on Golgi-associated vesicles.

Brefeldin A targets GTP exchange factors for ArfGTPases at the Golgi, blocking COPI vesicle formation which finally leads to the disassembly of the Golgi apparatus. Thus, this drug has been widely used to investigate the role of the Golgi complex in the trafficking pathways of a variety of proteins (Dinter and Berger, 1998; Nebenfuhr et al., 2002). BFA treatment of $\mathrm{HeLa}$ cells freshly transfected with EGFP-tagged reggie-1/flotillin-2 resulted in a diffuse 
A)

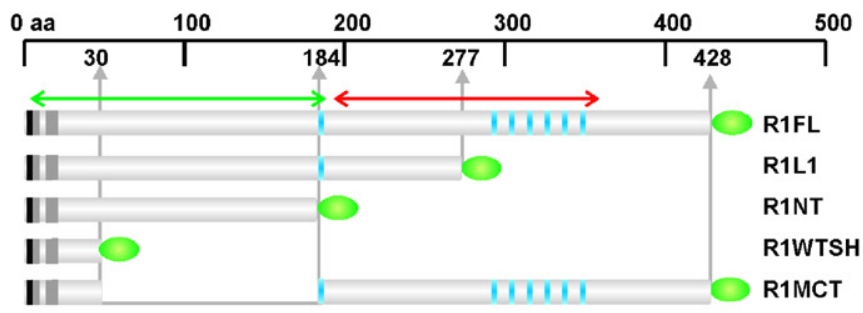

Acylation sites $\quad \stackrel{\text { SPFH domain }}{\longleftrightarrow} \quad \stackrel{\text { Flotillin domain EA repeats }}{\longleftrightarrow} \quad \underset{\text { EGFP tag }}{\longrightarrow}$
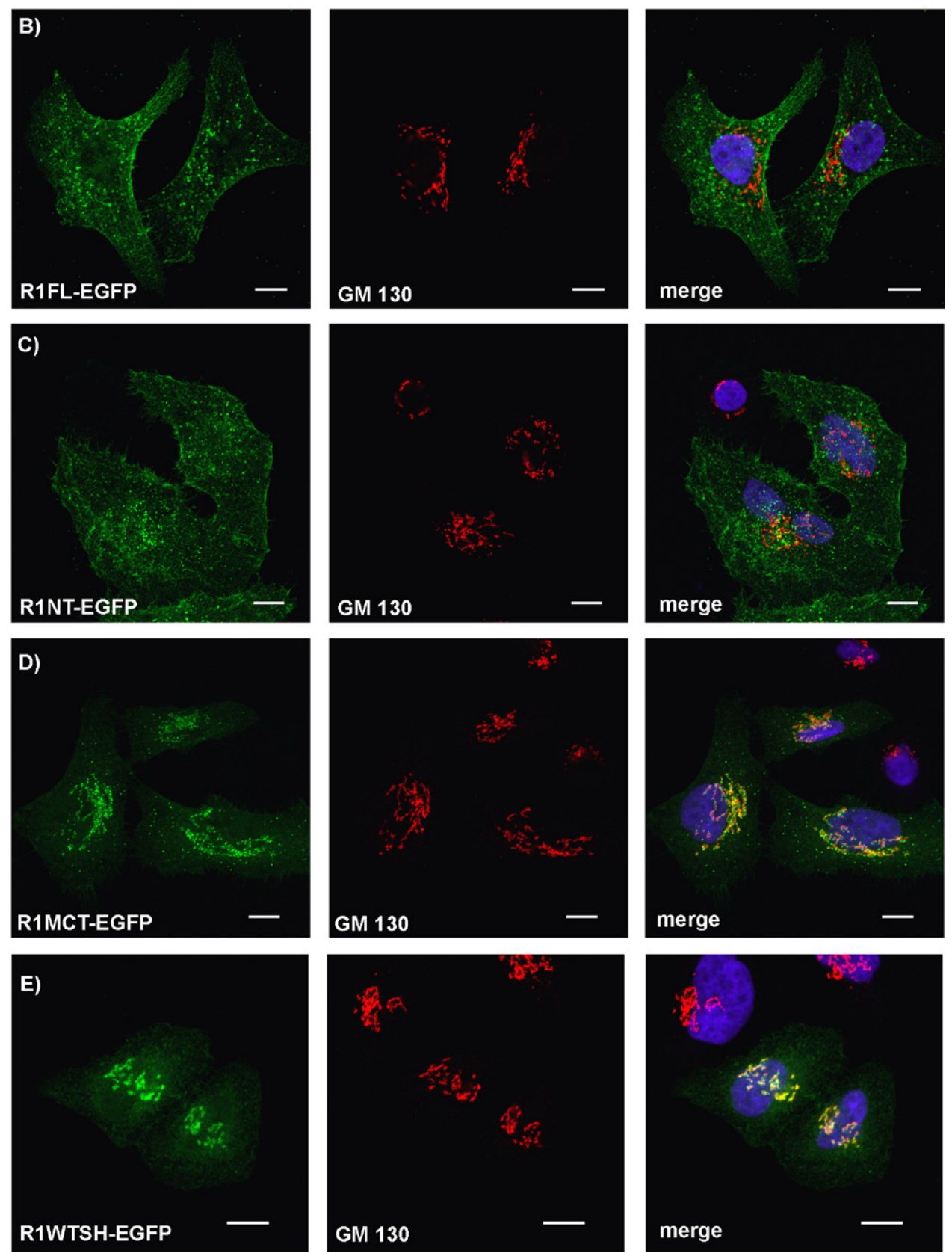

Fig. 1. Localization of reggie-1/flotillin-2 deletion mutants to the Golgi complex. (A) Schematic representation of the reggie-1/ flotillin-2 deletion mutants used in this study. Acylations, SPFH and flotillin domain, EA repeats, and position of the EGFP tag are indicated. (B-E) HeLa cells were transiently transfected with different EGFP-tagged reggie-1/flotillin-2 mutants, fixed and stained for the Golgi marker GM130 $24 \mathrm{~h}$ post-transfection. Confocal sections of cells expressing full-length reggie-1/flotillin-2 (B), a mutant lacking the flotillin domain (R1NT, C), a mutant lacking the SPFH domain (R1MCT, D), and the isolated membrane anchor domain (R1WTSH, E). The deletion mutants R1MCT and R1WTSH clearly co-localized with the GM130-stained Golgi. Bars $=10 \mu \mathrm{m}$. 

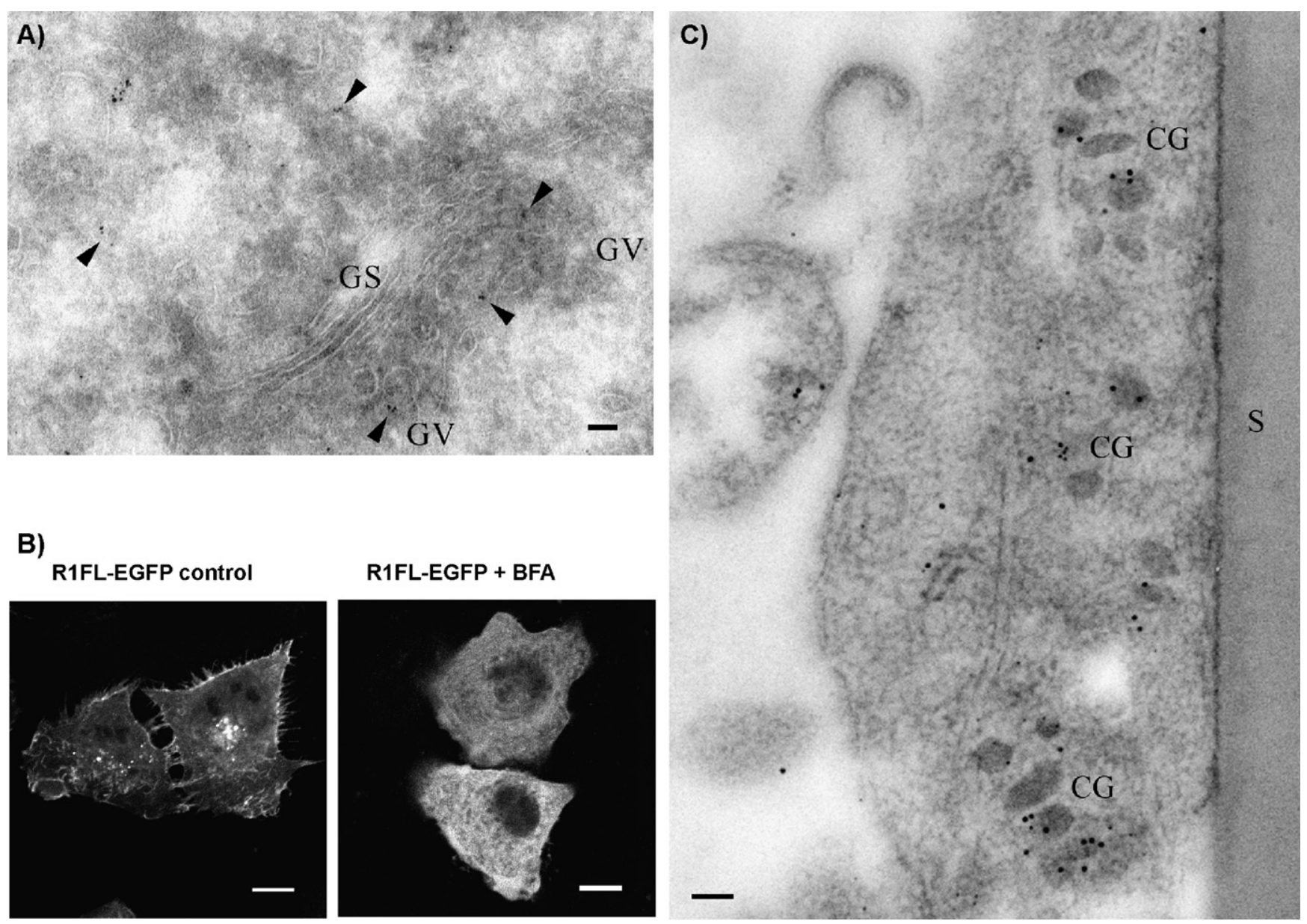

\section{B)}

R1FL-EGFP control

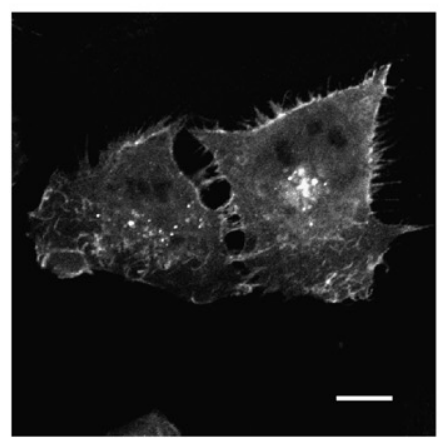

R1FL-EGFP + BFA

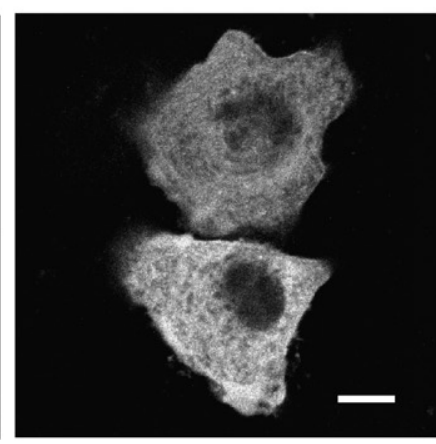

C)

Fig. 2. Reggie-1/flotillin-2 trafficking is Golgi dependent. (A) Cryo-sectioned Jurkat T cells were processed for immunogold labeling of endogenous reggie-1/flotillin-2 as detailed in "Material and methods". Reggie-1/flotillin-2 labeling as indicated by 5-nm gold grains (arrowheads) accumulated on vesicles $(\mathrm{GV})$ in the Golgi field but not in Golgi stacks (GS). (B) HeLa cells were transiently transfected with full-length reggie-1/flotillin-2 tagged with EGFP and treated with BFA $1 \mathrm{~h}$ post-transfection. Cells were fixed $4 \mathrm{~h}$ post-transfection, confocal images of representative control and BFA-treated cells are shown. BFA treatment clearly impaired the trafficking of reggie-1/flotillin-2. (C) PC12 cells were processed for immunogold labeling of endogenous reggie-1/flotillin-2 as detailed in "Material and methods". Reggie-1/flotillin-2 staining as indicated by 10-nm gold grains frequently accumulated on chromaffin granules (CG), S indicates the substrate. Bars $=0.1 \mu \mathrm{m}(\mathrm{A}, \mathrm{C}), 10 \mu \mathrm{m}(\mathrm{B})$.

cytosolic localization of the fusion protein, whereas reggie-1/flotillin-2 was efficiently targeted to the plasma membrane in control cells (Fig. 2B). BFA treatment did not change the localization of endogenous reggie-1/ flotillin-2 at steady state or of EGFP-tagged reggie-1/ flotillin-2 $48 \mathrm{~h}$ after transfection (data not shown). We obtained similar results in Jurkat T and PC12 cells, suggesting that trafficking of newly made reggie-1/ flotillin-2 is BFA sensitive and thus Golgi-dependent in these different cell types. Trafficking of reggie-2/ flotillin-1 was also BFA sensitive in HeLa and PC12 cells (data not shown), suggesting similar trafficking pathways of both proteins in these two cell lines.

Further evidence for a Golgi-dependent transport of reggie-1/flotillin-2 came from EM studies of PC12 cells. This cell line is derived from a rat phaeochromocytoma and contains dense core vesicles containing monoamines
(Martin and Grishanin, 2003). Reggie-1/flotillin-2 was clearly associated with these dense-core vesicles in PC12 cells as shown by immunogold staining and electron microscopy (Fig. 2C, enrichment factor of $134.7 \pm 51$ ). This was further verified by co-localization of chromogranin A with reggie-1/flotillin-2 at the light microscopic level (data not shown). As dense-core vesicles are finally assembled in the trans-Golgi network, these findings provide further evidence for trafficking of reggie-1/ flotillin-2 via the Golgi.

\section{Additional localizations of reggie-1/flotillin-2}

Endogenous reggie-1/flotillin-2 (data not shown) and reggie-1/flotillin-2-EGFP partially co-localized with lysotracker-positive compartments (Fig. 3A). In our 

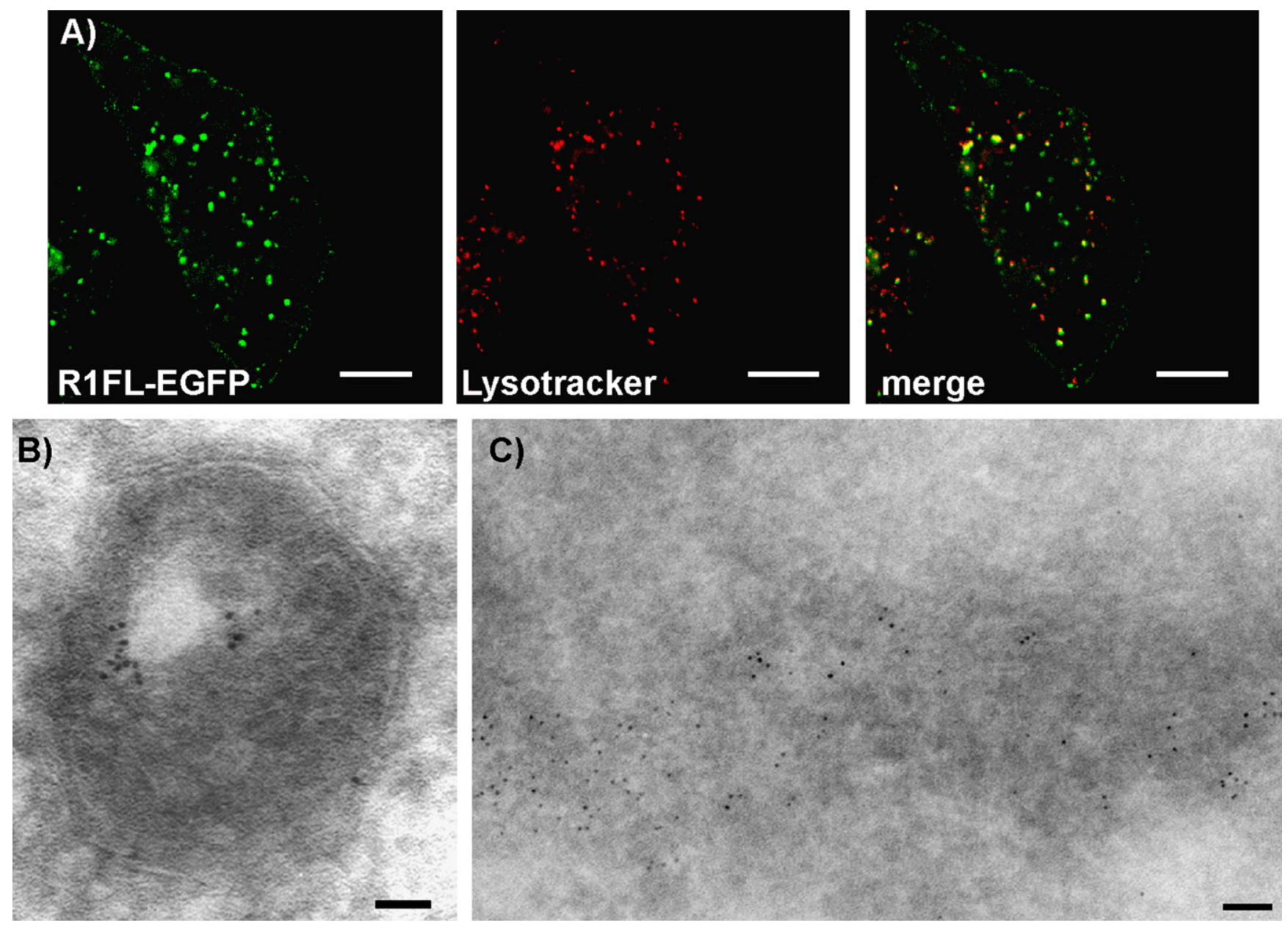

Fig. 3. Reggie-1/flotillin-2 localizes to lysosomes, multivesicular bodies and aggresomes. (A) HeLa cells transiently expressing EGFP-tagged full-length reggie-1/flotillin-2 were stained with lysotracker. A confocal section (linewise multitracking) is shown, where partial co-localization of large reggie-1/flotillin-2 vesicles and lysotracker-positive compartments is obvious. (B) EM analysis of a Jurkat $\mathrm{T}$ cell cryo-section showing a multivesicular body with labeling (6-nm gold) of endogenous reggie-1/flotillin-2. (C) Aggresome showing heavy reggie/flotillin labeling (5-nm gold, endogenous protein) in cryo-sectioned Jurkat $\mathrm{T}$ cells. Bars $=10 \mu \mathrm{m}$ (A), $0.1 \mu \mathrm{m}(\mathrm{B}, \mathrm{C})$.

immunogold EM studies, we observed strong labeling of multivesicular bodies (Fig. 3B, enrichment factor $68.8 \pm 33.9$ ) and other lysosomes (enrichment factor $111.8 \pm 42)$. However, we did not observe any colocalization of reggie-1/flotillin-2 with EEA1-positive early endosomes, both at the light and electron microscopic level. Surprisingly, we occasionally observed localization of endogenous reggie-1/flotillin-2 to aggresomes in our immunogold EM studies, particularly in Jurkat T cells (Fig. 3C).

\section{Reggie-1/flotillin-2-positive vesicles define a clathrin- independent vesicular pathway}

Consistent with a vesicular transport of reggie-1/ flotillin-2 to the plasma membrane, we observed numerous reggie-1/flotillin-2-EGFP-positive vesicles on their way to and from the plasma membrane in live-cell imaging experiments in various cell types (HeLa, Jurkat, PC12). Therefore, we employed total internal reflection fluorescence (TIRF) microscopy to investigate reggie/ flotillin vesicular trafficking near the plasma membrane in more detail. Reggie-1/flotillin-2 exhibited a punctate localization at the basal plasma membrane in HeLa cells (Fig. 4A), probably reflecting reggie/flotillin microdomains. In addition, we observed numerous brighter vesicles trafficking to and from the plasma membrane. After arriving in the thin section illuminated by TIRF microscopy, these vesicles underwent rapid movements before they became immobilized. During this immobilization, they exhibited the brightest fluorescence, suggesting that this stage reflects docking of the vesicles at the plasma membrane. After docking at the plasma membrane for several tens of seconds, the vesicles began to move again and either moved out of the evanescent field or engaged in a second round of immobilization (Fig. 4A and supplementary online material, Movie S1). 


\section{A) Reg1/Flot2 TIRF}
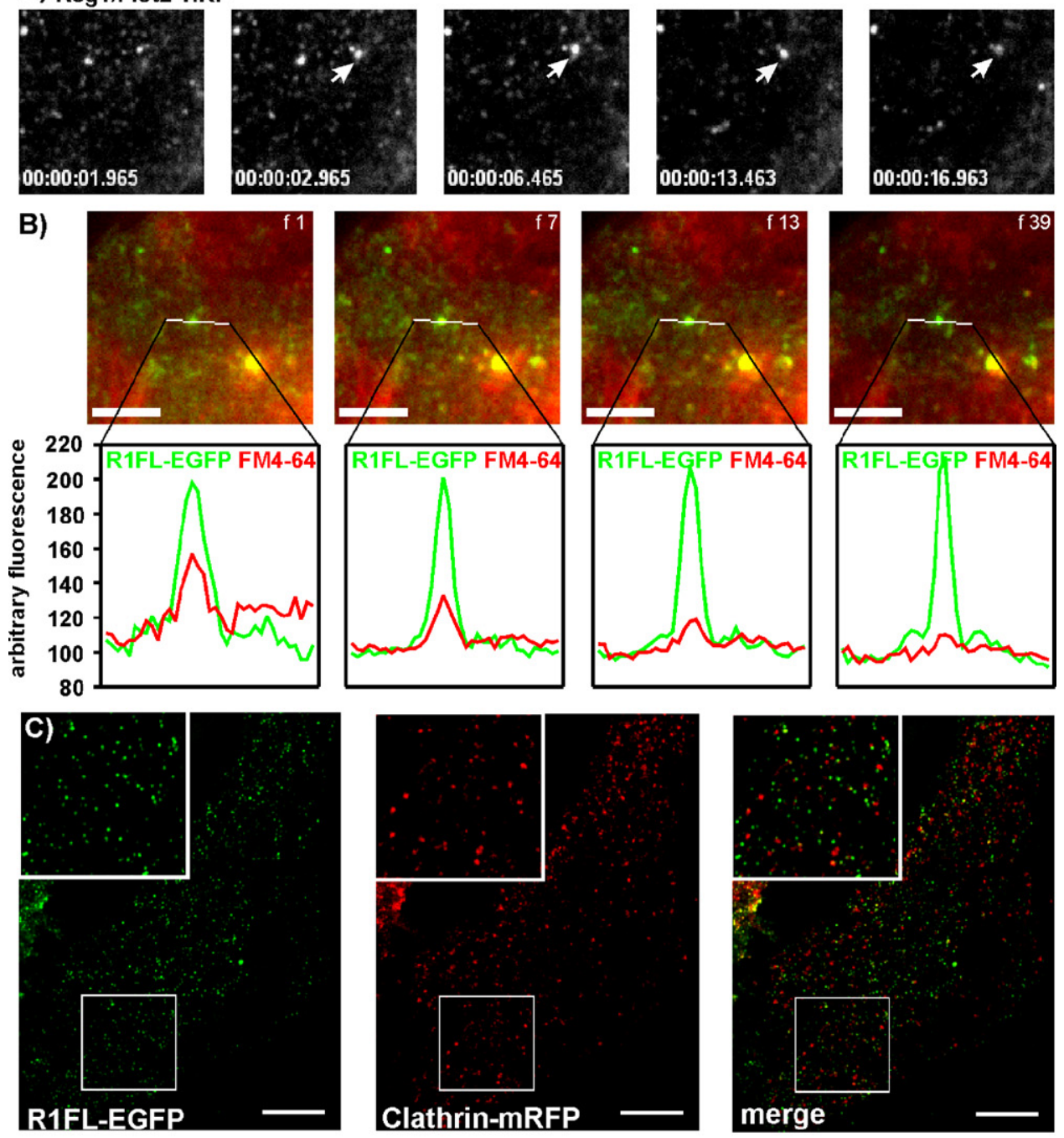

D)
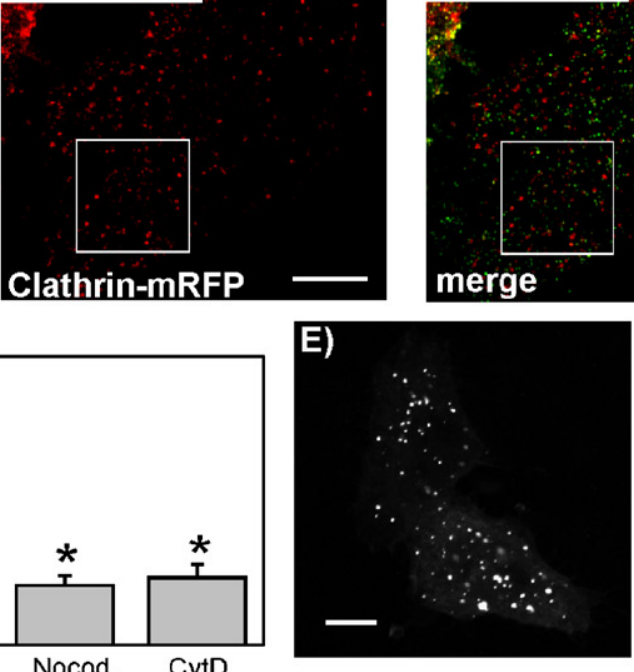

Fig. 4. Trafficking of reggie-1/flotillin-2 near the plasma membrane. (A) HeLa cells transiently expressing EGFP-tagged full-length reggie-1/flotillin-2 were imaged using TIRF microscopy. Reggie-1/flotillin-2 localized in clusters at the plasma membrane and on many vesicles exhibiting transient "kiss-and-run" interactions with the plasma membrane. (B) R1FL-EGFP-expressing HeLa cells were preloaded with FM4-64 to label all cellular membranes and individual vesicles approaching the membrane were imaged. After docking the FM4-64 fluorescence slowly became diffuse suggesting membrane fusion while R1FL-EGFP remained associated with the vesicle (representative example of three independent experiments with more than 15 cells each) (C) HeLa cells transiently expressing reggie-1/flotillin-2-EGFP and clathrin-mRFP were imaged using TIRF microscopy, both proteins occupied distinct membrane domains. (D-E) TIRF sequences of reggie-1/flotillin-2 trafficking were quantified as detailed in "Material and methods". Cholesterol was extracted using $12 \mathrm{mM}$ methyl- $\beta$-cyclodextrin $(\mathrm{M} \beta \mathrm{CD})$, microtubules were disrupted by short treatment with $1 \mu \mathrm{M}$ nocodazole, and F-actin was disrupted using $1 \mu \mathrm{M}$ cytochalasin D. Quantitative comparison (D) of 100 control, $33 \mathrm{M} \beta \mathrm{CD}$-treated, 32 nocodazole-treated, and 35 CytD-treated cells from at least three independent experiments are shown. Asterisk $(*)$ indicates statistical significance $(p<0.05$, Student's $t$-test). (E) Nocodazole treatment led to the accumulation of reggie-1/flotillin-2-positive vesicles in the cytosol. Bars $=10 \mu \mathrm{m}(\mathrm{C}, \mathrm{E})$. 
To test, whether the periods of immobilization at the plasma membrane involved fusion of the vesicle with the plasma membrane, we preloaded the cells with the styryl dye FM4-64 to label the membranes of all vesicles. When a reggie-1/flotillin-2 vesicle approached the membrane, both the R1FL-EGFP and FM4-64 channels showed clear peaks in fluorescence intensity (Fig. 4B, first image), which persisted until docking of the vesicle had occurred (Fig. 4B, second image). After docking, however, the FM4-64 fluorescence gradually diminished (Fig. 4B, third image) and finally the peak of FM4-64 fluorescence vanished in the area of the vesicle (Fig. 4B, last image). This suggests that the membrane of the vesicle had fused with the plasma membrane, so that the FM4-64 dye could diffuse from the vesicle membrane into the surrounding plasma membrane. However, since we never observed lateral diffusion of reggie-1/flotillin-2 fluorescence from the vesicle into the surrounding plasma membrane, we suggest that the reggie-1/flotillin-2 assembly remains on the vesicle throughout the docking cycle. These results imply that reggie-1/flotillin-2 vesicles engage in transient interactions with the plasma membrane only and that exo- and endocytosis in this pathway are tightly coupled. This is reminiscent of the kiss-and-run recycling described recently for caveolin (data not shown and Pelkmans and Zerial, 2005).

Reggie-1/flotillin-2 vesicle trafficking was independent of clathrin. Reggie-1/flotillin-2 demarcated plasma membrane domains which were clearly distinct from clathrin (Fig. 4C). Moreover, live-cell imaging experiments showed that reggie-1/flotillin-2-EGFP vesicle and clathrin pit dynamics occurred at distinct cellular sites (supplementary online material, Movie S2).

To further characterize reggie-1/flotillin-2 vesicle dynamics, we tested the cholesterol dependence of reggie-1/flotillin-2 trafficking. Cholesterol depletion using methyl- $\beta$-cyclo-dextrin reduced trafficking density to less than $60 \%$ of control levels (Fig. 4D). Disruption of microtubules by short incubation with nocodazole reduced the reggie- 1 /flotillin-2 trafficking density to less than $30 \%$ of control levels (Fig. 4D). Furthermore, disruption of microtubules by nocodazole led to a massive accumulation of reggie-1/flotillin-2-positive vesicles in the cytosol (Fig. 4E), which was reversed by nocodazole washout (data not shown). Similar reversible accumulations of intracellular vesicles were observed in Jurkat $\mathrm{T}$ cells after disturbance of microtubules by nocodazole, colchicine or cold shock (data not shown). Disruption of the actin cytoskeleton by cytochalasin $\mathrm{D}$ treatment also reduced reggie-1/ flotillin-2 trafficking significantly (Fig. 4D), but did not lead to any accumulation of vesicles in the cell. Thus, reggie-1/flotillin-2 vesicular trafficking is clathrin-independent, but cholesterol and microtubule dependent, which are characteristics of an unconventional, microdomain-mediated trafficking pathway.

\section{Reggie-2/flotillin-1 and stomatin-1 define vesicular pathways similar to reggie-1/flotillin-2}

Reggie-2/flotillin-1 tagged with EGFP at its C-terminus also showed vesicular cycling again engaging in transient interactions with the plasma membrane only (Fig. 5A and supplementary online material, Movie S3), very similar to reggie-1/flotillin-2. The trafficking density we observed in TIRF time-lapse sequences was also very similar to that of reggie-1/flotillin-2 (data not shown). However, reggie-1/flotillin-2 and reggie-2/flotillin-1 exhibited partial co-localization in HeLa cells. Although they co-localized in plasma membrane microdomains (Fig. 5B) and on vesicles inside the cell (data not shown), some smaller vesicles and some plasma membrane microdomains were distinctively labeled by only one of the two reggies/flotillins (Fig. 5C). Reggie-1/flotillin-2 and reggie-2/flotillin-1 are members of the SPFH-domain protein family, which include also stomatins, prohibitins, erlins and podocin (Tavernarakis et al., 1999; Browman et al., 2006; Rivera-Milla et al., 2006). Stomatin-1-labeled vesicles also exhibited cycles of transient docking at the plasma membrane (Fig. 5C), although stomatin-1 vesicles were less abundant than reggie-1/flotillin-2 vesicles in steady-state conditions (Fig. 5D). Stomatin-1 microdomains and vesicles at the plasma membrane did not colocalize with reggie-1/flotillin-2 (Fig. 5E) or reggie-2/ flotillin-1 (data not shown). Inside the cell, however, both reggie-1/flotillin-2 and stomatin-1 co-localized on larger vesicles (Fig. 5F). Thus, SPFH-domain proteins like reggie-1/flotillin-2, reggie-2/flotillin-1 and stomatin not

Fig. 5. Trafficking of reggie-2/flotillin-1 and stomatin-1 near the plasma membrane. (A) HeLa cells transiently expressing EGFPtagged full-length reggie-2/flotillin-1 were imaged using TIRF microscopy. Reggie-2/flotillin-1 localized in clusters at the plasma membrane and on many vesicles exhibiting transient "kiss-and-run" interactions with the plasma membrane, similar to reggie-1/ flotillin-2. (B) HeLa cells transiently expressing reggie-1/flotillin-2-EGFP and reggie-2/flotillin-1-HA were fixed, stained with HAspecific antibodies and imaged using TIRF microscopy. Reggie-1/flotillin-2 and reggie-2/flotillin-1 partially co-localized at the plasma membrane. (C, D) HeLa cells transiently expressing stomatin-1-EGFP were imaged using TIRF microscopy. (D) Stomatin-1 vesicles exhibited similar trafficking as reggie-1/flotillin-2, but trafficking density was much lower. (E, F) HeLa cells transiently expressing stomatin-1-EGFP and reggie-1/flotillin-2-HA were fixed, stained with HA-specific antibodies and imaged using TIRF and confocal microscopy. Reggie-1/flotillin-2 and stomatin-1 did not co-localize at the plasma membrane, but partially co-localized on intracellular vesicles ( $F$, boxed areas are shown enlarged in $G$ ). Bars $=10 \mu \mathrm{m}$. 
A) Reg2/Flot1 TIRF
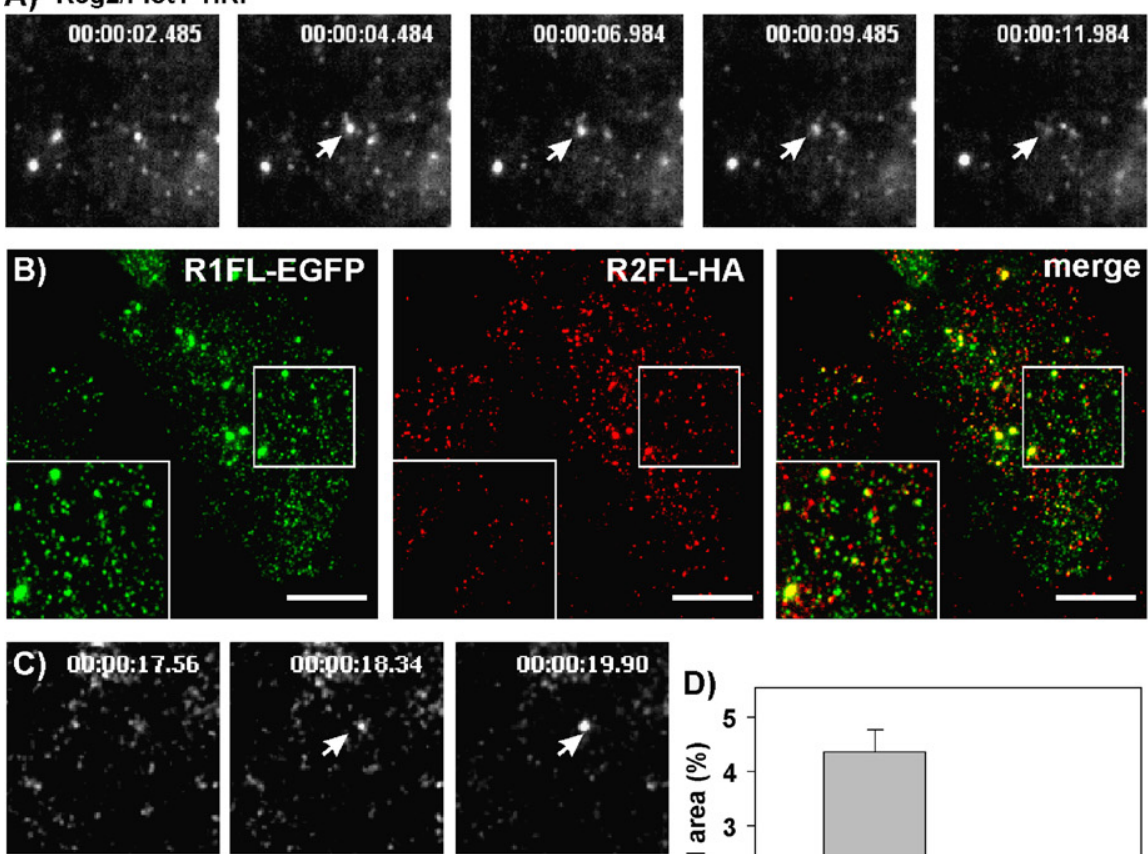

00:00:33.57
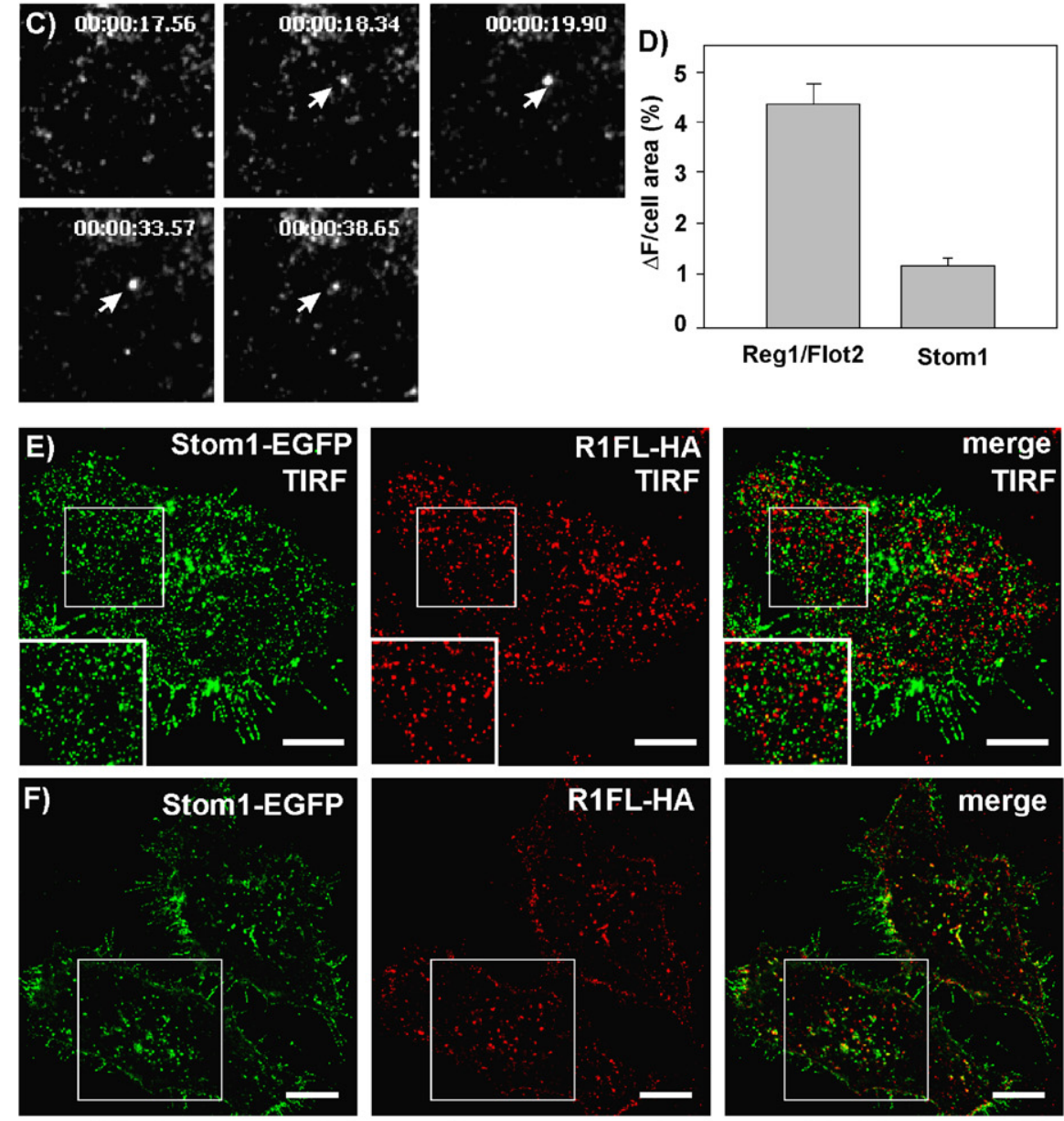

G)
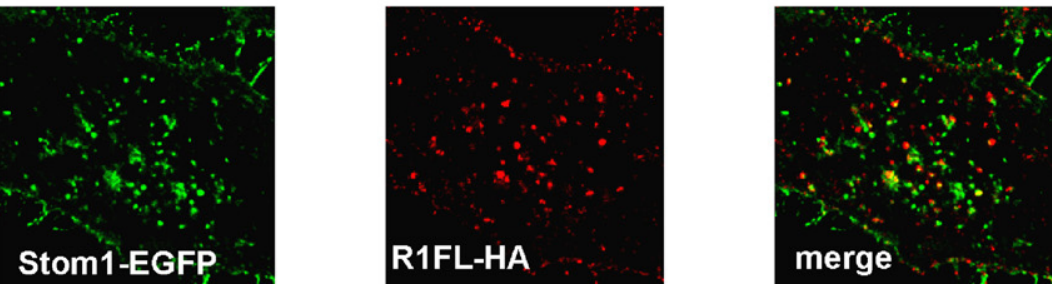
only form membrane microdomains similar to caveolae (Langhorst et al., 2005) but they also seem to play a role in vesicular trafficking like caveolin (Pelkmans and Zerial, 2005), defining specialized endo- or exocytotic pathways.

\section{Reggie-1/flotillin-2 trafficking is regulated by growth factors and cell-cell contact formation}

Next, we tested whether the cycling of reggie-1/flotillin2 vesicles is constitutive or regulated. While we observed only few vesicular events in serum-starved cells, stimulation with serum significantly increased the number of vesicles observed in the evanescent field as well as their mobility (Figs. 6A-C). Inhibition of protein phosphatases by okadaic acid strongly stimulated reggie-1/flotillin-2 trafficking (Fig. 6C). We tested several serum components to see whether they are able to stimulate reggie-1/flotillin-2 vesicle trafficking. Epidermal growth factor (EGF) stimulated reggie-1/flotillin-2 trafficking to a similar extent as serum (Fig. 6C). The hormone analog dexamethasone, an agonist of G-protein-mediated signaling did not significantly change reggie-1/flotillin-2 trafficking (Fig. 6C). Similarly, lysophosphatidic acid (LPA) stimulation did also not change reggie-1/flotillin-2 trafficking (data not shown). As expected, holo-transferrin, a known cargo of clathrin-coated pits, was without effect on reggie-1/ flotillin-2 trafficking (Fig. 6C). However, incubation with low-density lipoproteins (LDL), which are known to be internalized via clathrin-coated pits and represent a physiological way to load cells with cholesterol, largely increased reggie-1/flotillin-2 trafficking, again highlighting the cholesterol dependence of reggie-1/flotillin-2 trafficking. Taken together, these data suggest, that reggie-1/flotillin-2 trafficking is regulated by external stimuli. This is further supported by our observation that reggie-1/flotillin-2 trafficking is regulated by cellcell contact formation. As described above, we observed numerous reggie-1/flotillin-2 vesicles in subconfluent HeLa cell cultures in the presence of serum. However, in confluent cultures vesicle trafficking was significantly reduced even in the presence of serum (Fig. 6D), indicating that upon establishment of cell-cell contacts, reggie-1/flotillin-2 trafficking is downregulated.

The EGF receptor (EGFR) is normally internalized via clathrin-coated pits, but temporally resides in membrane microdomains (Le Roy and Wrana, 2005). As EGF stimulated reggie-1/flotillin-2 trafficking, we tested how EGFR internalization and reggie-1/flotillin-2 trafficking are linked. Stimulation of starved cells with $30 \mathrm{ng} / \mathrm{ml} \mathrm{EGF}$ induced the formation of large EGFR clusters at the plasma membrane (Fig. 7A) within 5 min. However, these clusters did not significantly overlap with reggie-1/flotillin-2 microdomains. Within 15 min, EGFR-positive vesicles accumulated inside the cells, but
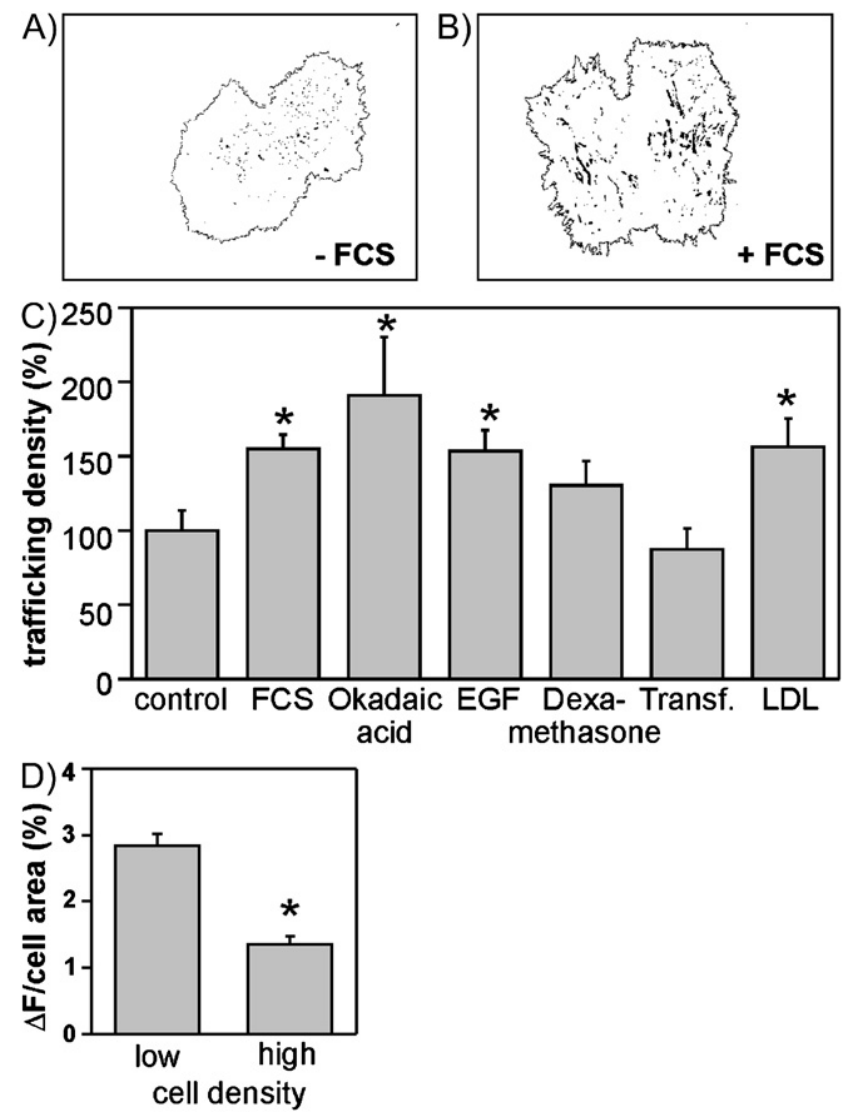

Fig. 6. Reggie-1/flotillin-2 trafficking is stimulated by serum, EGF and okadaic acid, but inhibited by cell-cell contact formation. TIRF sequences of reggie-1/flotillin-2 trafficking were quantified as detailed in "Material and methods". (A, B) Representative binaries of 51 serum-starved (A) and 53 serumstimulated (B) cells from three independent experiments. (C) Quantitative comparison of the trafficking density in cells stimulated with serum $(n=53)$, okadaic acid $(100 \mathrm{nM}$, $n=29)$, EGF $(30 \mathrm{ng} / \mathrm{ml}, n=52)$, dexamethasone $(100 \mathrm{nM}$, $n=62)$, holo-transferrin $(50 \mu \mathrm{g} / \mathrm{ml}, n=101)$ and LDL $(50 \mu \mathrm{g} /$ $\mathrm{ml}, n=68)$ relative to starved control cells $(n=51)$. (D) Trafficking was downregulated by cell-cell contact formation. Cells were transfected with reggie-1/flotillin-2-EGFP and seeded at different densities. Quantitative comparison of the trafficking density in 58 cells at low and 58 cells at high density from three independent experiments are shown. Asterisk $(*)$ indicates statistical significance $(p<0.05$, Student's $t$-test).

again, we observed no significant co-localization of reggie-1/flotillin-2 and EGFR (Fig. 7B). Thus, EGF stimulates reggie-1/flotillin-2 trafficking indirectly, while the EGFR is endocytosed via other pathways, i.e. clathrin-coated pits (Le Roy and Wrana, 2005).

\section{Reggie-1/flotillin-2 vesicles are not involved in endocytosis of GPI-anchored proteins}

So far, our results suggest that reggie-1/flotillin-2 might be involved in the controlled delivery and retrieval of 

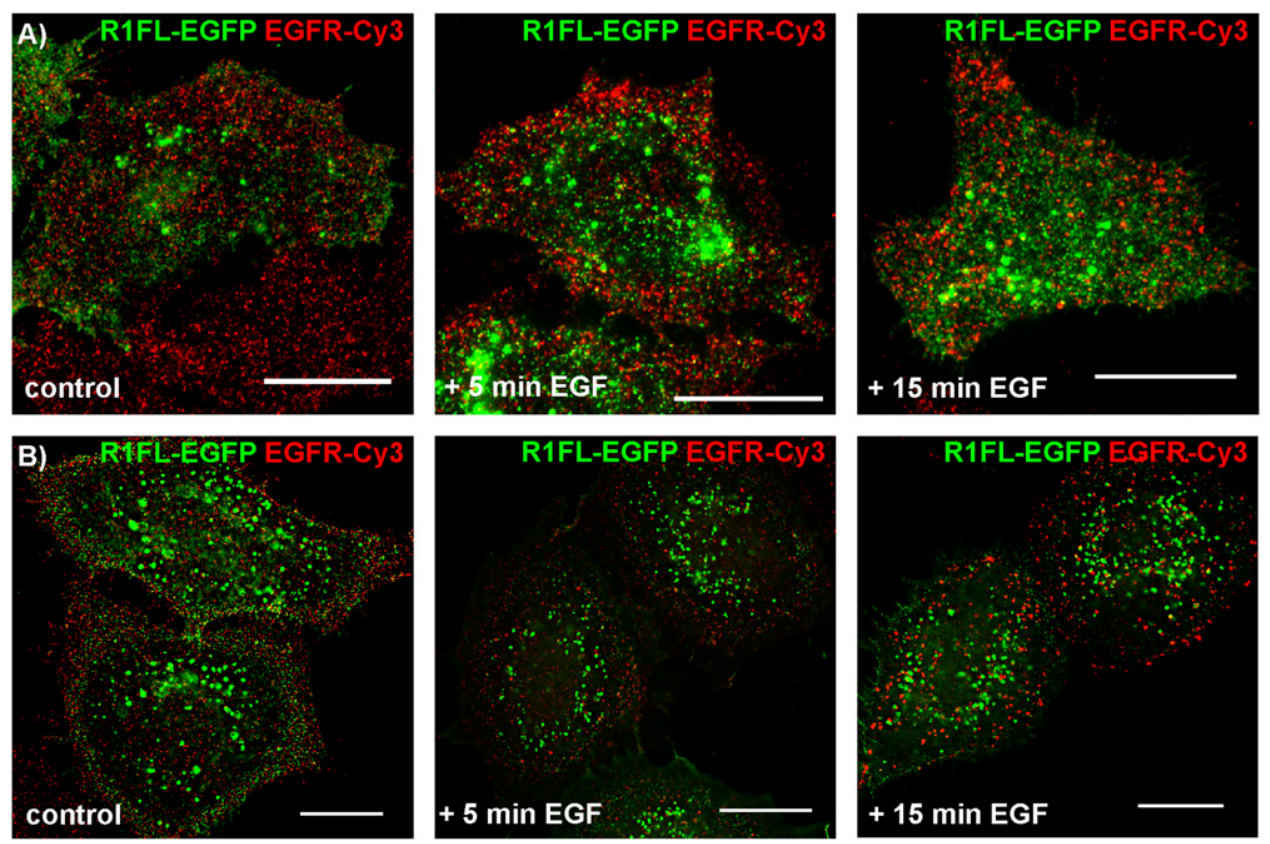

Fig. 7. Reggie-1/flotillin-2 is not involved in EGFR endocytosis. HeLa cells were stimulated with $30 \mathrm{ng} / \mathrm{ml} \mathrm{EGF}$ for the indicated times, fixed, stained with EGFR-specific antibodies and imaged using TIRF (A) and confocal (B) microscopy. No significant co-localization of reggie-1/flotillin-2 and EGFR was observed. Bars $=20 \mu \mathrm{m}$.

proteins to and from the plasma membrane by regulated cycling. We have previously shown that both reggies/ flotillins are closely associated with certain GPI-anchored proteins (Stuermer et al., 2001, 2004) and a recent publication implicated reggie-2/flotillin-1 in unconventional endocytosis of GPI-anchored proteins (Glebov et al., 2006). Therefore, we tested whether reggie-1/ flotillin-2 vesicles are involved in trafficking of GPIanchored proteins. Reggie-1/flotillin-2 did not co-localize with either GPI-CFP(DAF) (CFP fused to the GPI signal of the decay accelerating factor (DAF)) (Legler et al., 2005) (data not shown) nor with the differentially localized GPI-EGFP(PrP) (EGFP fused to the GPI signal of $\operatorname{PrP}^{\mathrm{c}}$ from mouse) at the plasma membrane (Fig. 8A) or on intracellular vesicles (data not shown), ruling out that reggie-1/flotillin-2 trafficking is generally linked with GPIanchored proteins. We have previously shown, that crosslinking of $\operatorname{PrP}^{\mathrm{c}}$ in lymphocytes leads to the close association of $\mathrm{PrP}^{\mathrm{c}}$ and the reggies/flotillins in plasma membrane microdomains and to signaling, which is downregulated by endocytosis of $\operatorname{PrP}^{\mathrm{c}}$ clusters and the reggies and transfer to lysosomes (Stuermer et al., 2004). In some cells, $\operatorname{PrP}^{\mathrm{c}}$ is thought to be internalized by caveolae (Peters et al., 2003) which are absent in lymphocytes, so we tested whether $\operatorname{PrP}^{\mathrm{c}}$ is endocytosed via a reggie/flotillin-dependent pathway after cross-linking in lymphocytes. Immunogold EM of Jurkat T cells after $\operatorname{PrP}^{\mathrm{c}}$ cross-linking revealed the accumulation of $\operatorname{PrP}^{\mathrm{c}}$ in coated pits (Fig. 8B, enrichment factor $>1000$ ) and vesicles (Fig. 8C) and later in early endosomes identified by EEA1 labeling (Fig. 8D, enrichment factor $51.4 \pm 16.2$ ).
In agreement with our results presented above, reggie-1/ flotillin-2 was observed neither in coated pits nor in early endosomes. $\operatorname{PrP}^{\mathrm{c}}$ endocytosis after cross-linking was strongly inhibited by dominant-negative Eps15 (Fig. 8E) and dynamin (Fig. 8F) mutants as well as by hypotonic shock (data not shown), proving that in lymphocytes, $\operatorname{PrP}^{\mathrm{c}}$ is taken up via clathrin-coated pits, despite its close association with the reggies/flotillins in plasma membrane microdomains. The general mechanisms of $\operatorname{PrP}^{\mathrm{c}}$ endocytosis are still unclear (reviewed in Prado et al. (2004)). Both, endocytosis via caveolae (Peters et al., 2003), and uptake via clathrin-coated pits (Shyng et al., 1994; Sunyach et al., 2003) were described. The absence of caveolae and the close association of $\operatorname{PrP}^{\mathrm{c}}$ and the reggies/ flotillins made a reggie/flotillin-mediated uptake of $\operatorname{PrP}^{\mathrm{c}}$ in lymphocytes conceivable. But even in lymphocytes, a reggie/flotillin-mediated $\operatorname{PrP}^{\mathrm{c}}$ internalization was not observed. Both, reggies/flotillins and $\operatorname{PrP}^{\mathrm{c}}$ end up in multivesicular bodies (Fig. 8G) after endocytosis from the signaling macrodomain where $\operatorname{PrP}^{\mathrm{c}}$ co-clusters with the reggies/flotillins after cross-linking in lymphocytes, but our results show that $\operatorname{PrP}^{\mathrm{c}}$ is taken up via clathrin-coated pits, while the reggies/flotillins do not enter this pathway. Thus, both $\operatorname{PrP}^{\mathrm{c}}$ and the reggies/flotillins must reach the lysosomal compartments via different pathways.

\section{Discussion}

Our data demonstrate, that early trafficking of reggie1/flotillin-2 is Golgi-dependent and that signals for 

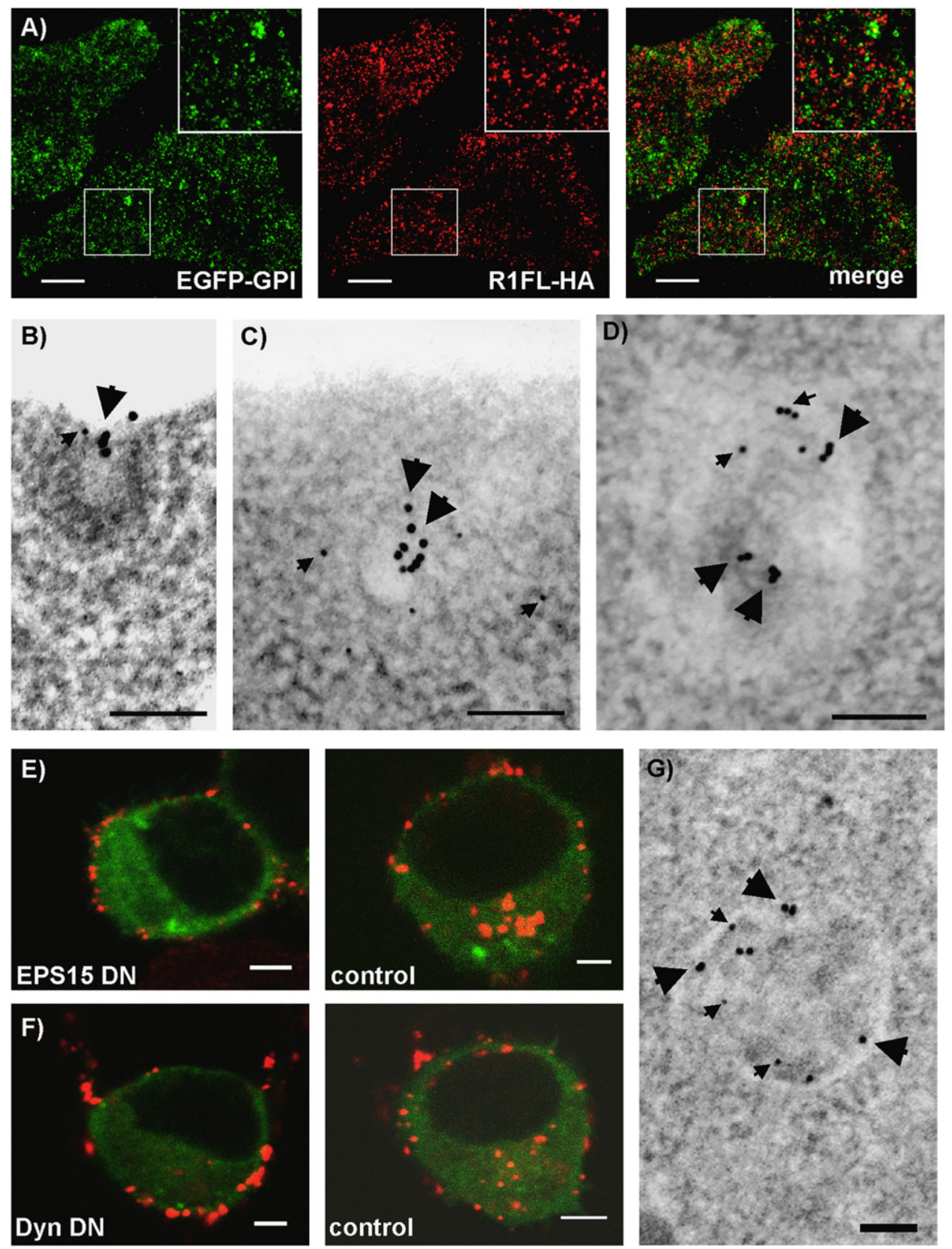

Fig. 8. Reggie-1/flotillin-2 is not involved in endocytosis of GPI-GFP or PrP ${ }^{\mathrm{c}}$. (A) HeLa cells transiently expressing EGFPGPI(PrP) and reggie-1/flotillin-2-HA were fixed, stained with HA-specific antibodies and imaged using TIRF microscopy. EGFPGPI clustered at the plasma membrane, but occupied domains distinct from those formed by reggie-1/flotillin-2. (B, C) Jurkat T cells were stimulated by antibody-mediated $\mathrm{PrP}^{\mathrm{c}}$ cross-linking and processed for immunogold EM as detailed in "Material and methods". PrP $\mathrm{P}^{\mathrm{c}}(10-\mathrm{nm}$ gold, large arrowheads) is endocytosed via coated pits (B) and endocytic vesicles (C), while reggie-1/flotillin2 (5-nm gold, small arrowheads) is excluded from these structures. (D) $\operatorname{PrP}^{\mathrm{c}}$ (10-nm gold, large arrowheads) is then found in early endosomes marked by EEA1 staining (5-nm gold, small arrowheads). (E) Transient transfection with a dominant-negative Eps-15 mutant (green) inhibits $\operatorname{PrP}^{\mathrm{c}}$ endocytosis after antibody-mediated cross-linking. $\operatorname{PrP}^{\mathrm{c}}$ (red) stays clustered at the plasma membrane, but is readily internalized in control-transfected cells. (F) Transient transfection with a dominant-negative dynamin mutant (green) similarly inhibits $\operatorname{PrP}^{\mathrm{c}}$ (red) endocytosis after cross-linking. $(\mathrm{G})$ Both $\operatorname{PrP}^{\mathrm{c}}$ (10-nm gold, large arrowheads) and reggie-1/flotillin-2 (5$\mathrm{nm}$ gold, small arrowheads) are associated with the same multivesicular body. Bars $=10 \mu \mathrm{m}(\mathrm{A}), 0.1 \mu \mathrm{m}(\mathrm{B}-\mathrm{D}, \mathrm{G}), 5 \mu \mathrm{m}(\mathrm{E}, \mathrm{F})$.

Golgi association and transit are encoded in the amino acid sequence of reggie-1/flotillin-2. At the plasma membrane, reggie-1/flotillin-2 exhibited vesicular cycling regulated by cell-cell contact formation, cholesterol loading and growth factors. This pathway was, however, not involved in endocytosis of the EGFR nor of GPIanchored proteins like GPI-EGFP or $\operatorname{PrP}^{\mathrm{c}}$, even though reggie/flotillin is known to closely associate with $\operatorname{PrP}^{\mathrm{c}}$ 
and other GPI-anchored proteins. The reggie-1/flotillin2-related proteins reggie-2/flotillin-1 and stomatin-1 exhibit vesicular behavior similar to reggie-1/flotillin-2, but at distinct sites of the plasma membrane, suggesting that regulated vesicular cycling might be a general feature of SPFH-domain proteins.

\section{Golgi-dependent trafficking of reggie-1/flotillin-2}

Our results suggest Golgi-dependent early trafficking of reggie-1/flotillin-2. Reggie-1/flotillin-2 is myristoylated at Gly2 (Neumann-Giesen et al., 2004). Myristoylation is generally thought to occur co-translationally, thus rendering the protein prone to membrane interaction early during biosynthesis (Farazi et al., 2001). Thus, reggie-1/flotillin-2 might associate with membranes of the secretory pathway co-translationally, explaining the Golgi-dependent transport of freshly synthesized protein. Reggie-1/flotillin-2 is additionally palmitoylated predominantly at Cys4 and to a lower extent at Cys19 and Cys20 (Neumann-Giesen et al., 2004). Palmitoylation occurs post-translationally and apparently at different subcellular locations (Huang and El-Husseini, 2005), but many of the DHHC proteins involved in palmitoylation reside in the Golgi complex (Huang et al., 2004; Keller et al., 2004; Huang and El-Husseini, 2005; Rocks et al., 2005). Palmitoylation of reggie-1/ flotillin-2 might therefore occur during its transit through the Golgi. Golgi exit is somehow linked to the presence of the SPFH domain, as mutants lacking this domain accumulate at the Golgi complex. Therefore, protein interactions mediated by the SPFH domain apparently regulate Golgi exit. We have recently shown that the SPFH domain of reggie-1/flotillin-2 interacts with filamentous actin and that this interaction is crucial for reggie-1/flotillin-2 localization and mobility at the plasma membrane (Langhorst et al., 2007). One could envision that interaction with actin is also important for reggie/flotillin vesicle trafficking and the localization and mobility of reggie/flotillin-coated vesicles, both at the Golgi and at the plasma membrane, where we observed hot-spots of reggie/flotillin trafficking, which where often aligned along cytoskeletal structures. Our results are consistent with Golgi-dependent biosynthetic trafficking of reggie-1/flotillin-2. However, we cannot formally exclude retrograde trafficking to and retrograde accumulation of the deletion mutants at the Golgi.

Golgi-dependent trafficking of reggie-1/flotillin-2 is in apparent contradiction to a report on Golgi-independent trafficking of reggie-2/flotillin-1. However, reggie2/flotillin-1 is not myristoylated, but palmitoylated mainly at Cys34 (Morrow et al., 2002; Langhorst et al., 2005). Thus, reggie-2/flotillin-1 interaction with membranes is regulated post-translationally. Being anchored to membranes via reversible palmitoylation opens up non-vesicular pathways for reggie-2/flotillin-1, which are most probably inaccessible for the irreversibly myristoylated reggie-1/flotillin-2. In addition, different localizations and/or expression of palmitoylation enzymes might also explain the different trafficking pathways reported for reggie-2/flotillin-1 in HeLa (Golgi dependent) (Gkantiragas et al. (2001) and our own data) and BHK cells (Golgi independent) (Morrow et al., 2002).

\section{Regulated vesicular cycling of reggie-1/flotillin-2 at the plasma membrane}

Cycling of reggie-1/flotillin-2 was stimulated by serum and EGF as well as by phosphatase inhibitors, but inhibited by cell-cell contact formation, suggesting that reggie-1/flotillin-2 cycling is regulated by the integration of cellular signaling pathways. This fits well with a recent report showing that plasma membrane localization of reggie-1/flotillin-2 can be regulated by tyrosine phosphorylation (Neumann-Giesen et al., 2007). However, in contrast to the study above, where the EGFR was found to co-localize with reggie-1/flotillin-2 in endocytic vesicles, our data suggest that reggie-1/ flotillin-2 vesicles are not involved in EGFR endocytosis. We never observed significant co-localization between EGFR and reggie-1/flotillin-2. Reggie-1/flotillin-2 trafficking was dependent on cholesterol. Cholesterol extraction reduced, while cholesterol loading increased vesicle trafficking. Whether reggie-1/flotillin2 vesicles need cholesterol to be functional or whether they are involved in cholesterol transport through the cell remains to be investigated.

GPI-anchored proteins in general are proposed to be a cargo for unconventional, microdomain-mediated endocytosis (Nichols, 2002). Reggie-2/flotillin-1 was recently shown to be involved in endocytosis of CD59 (Glebov et al., 2006). However, different GPI-anchored proteins behave differently and have different preferences for plasma membrane microdomains (Madore et al., 1999; Li et al., 2003). We did not observe a general association of reggie-1/flotillin-2 with either GPI-FPs or with $\operatorname{PrP}^{\mathrm{c}}$, suggesting that the reggies/flotillins are either not generally involved in the endocytosis of GPIanchored proteins or used only by a specific subset of GPI-anchored proteins.

Reggie-1/flotillin-2, reggie-2/flotillin-1 and stomatin-1 showed similar vesicle dynamics at the plasma membrane. Localization and characteristics of their vesicular trafficking suggest that the reggies/flotillins define similar and sometimes distinct membrane domains and vesicles. Both reggies/flotillins can form homo- as well as hetero-oligomers (reviewed in Langhorst et al. (2005)). Thus, while the distinct microdomains and vesicles 
might represent homo-oligomers of either protein, the mixed domains and vesicles might represent heterooligomers. It is tempting to speculate, that microdomains and vesicles with reggie/flotillin homo- and hetero-oligomers might serve similar functions but interact with separate sets of proteins. However, a recent publication has claimed that co-assembly of both reggies/flotillins is necessary for membrane invagination and vesicle budding, suggesting that reggie/flotillin oligomers actually act as vesicle coat (Frick et al., 2007). Further studies will be needed to investigate the role of reggie/flotillin homo- and hetero-oligomers in trafficking. Stomatin-containing microdomains and vesicles might serve again similar functions for other sets of proteins. As stomatin-1 trafficking was quite low under standard culture conditions, stomatin trafficking might be important only in special situations. However, all three pathways partly converged on common intracellular compartments, again suggesting that they are variations on a common theme. More work is needed to clarify the exact role of each of these pathways alone and in combination.

Regulated cycling of membrane proteins enables cells to rapidly modulate protein levels at the plasma membrane. Changes in the cycling rate of a vesicular pathway will immediately affect the distribution of its associated proteins between intracellular compartments and the plasma membrane (Royle and Murrell-Lagnado, 2003). This mechanism enables neurons to rapidly translocate large numbers of the cation channel TRPC5 from vesicles held in reserve in the cytosol to the plasma membrane upon growth factor stimulation (Bezzerides et al., 2004). Another example of a protein regulated by cycling between the plasma membrane and intracellular storage vesicles is the glucose transporter Glut 4 - insulin stimulates its insertion into the plasma membrane of adipocytes or muscle cells from an intracellular vesicular pool (Dugani and Klip, 2005). Interestingly, reggie-2/ flotillin-1, which exhibits kiss-and-run cycling at the plasma membrane (our experiments presented above), was repeatedly implicated in Glut4 trafficking both in adipocytes (Baumann et al., 2000; Kimura et al., 2001) and muscle cells (Fecchi et al., 2006). While the work in adipocytes concentrated on the biochemical characterization of a reggie-2/flotillin-1-dependent activation of TC10 (Baumann et al., 2000; Kimura et al., 2001), a recent report in muscle cells investigated the subcellular localization and association of Glut4 and reggie-2/ flotillin-1. This work shows a translocation of reggie-2/ flotillin-1- and Glut4-containing domains to the plasma membrane upon insulin stimulation (Fecchi et al., 2006), suggesting that the reggies/flotillins might be involved in regulating plasma membrane Glut4 levels by regulated cycling.

The scaffolds provided by the SPFH-domain proteins reggie-1/flotillin-2, reggie-2/flotillin-1, stomatin-1 and putatively others might therefore serve a dual function, similar to the functions assigned to caveolae, i.e. they not only build stable membrane domains for protein complex assembly and signaling, but also act as recruitment factors for specialized vesicular pathways. Understanding these different pathways in detail may shed new light on pathogen entry pathways or open up new routes of drug delivery.

\section{Acknowledgments}

This work was supported by grants from the Deutsche Forschungsgemeinschaft DFG (SFB-TR11), the Ministerium Forschung, Wissenschaft und Kunst BadenWürttemberg (TSE program) and the Fonds der Chemischen Industrie. We thank S. Kolassa and L. Nejedli for their excellent EM preparations.

\section{Appendix A. Supplementary Materials}

Supplementary data associated with this article can be found in the online version at doi:10.1016/j.ejcb. 2007.12.001.

\section{References}

Abramoff, M.D., Magelhaes, P.J., Ram, S.J., 2004. Image processing with ImageJ. Biophoton. Int. 11, 36-42.

Baumann, C.A., Ribon, V., Kanzaki, M., Thurmond, D.C., Mora, S., Shigematsu, S., Bickel, P.E., Pessin, J.E., Saltiel, A.R., 2000. CAP defines a second signalling pathway required for insulin-stimulated glucose transport. Nature 407, 202-207.

Bezzerides, V.J., Ramsey, I.S., Kotecha, S., Greka, A., Clapham, D.E., 2004. Rapid vesicular translocation and insertion of TRP channels. Nat. Cell Biol. 6, 709-720.

Bickel, P.E., Scherer, P.E., Schnitzer, J.E., Oh, P., Lisanti, M.P., Lodish, H.F., 1997. Flotillin and epidermal surface antigen define a new family of caveolae-associated integral membrane proteins. J. Biol. Chem. 272, 13793-13802.

Browman, D.T., Resek, M.E., Zajchowski, L.D., Robbins, S.M., 2006. Erlin-1 and erlin-2 are novel members of the prohibitin family of proteins that define lipid-raft-like domains of the ER. J. Cell Sci. 119, 3149-3160.

Dinter, A., Berger, E.G., 1998. Golgi-disturbing agents. Histochem. Cell Biol. 109, 571-590.

Dugani, C.B., Klip, A., 2005. Glucose transporter 4: cycling, compartments and controversies. EMBO Rep. 6, 1137-1142.

Farazi, T.A., Waksman, G., Gordon, J.I., 2001. The biology and enzymology of protein N-myristoylation. J. Biol. Chem. 276, 39501-39504.

Fecchi, K., Volonte, D., Hezel, M.P., Schmeck, K., Galbiati, F., 2006. Spatial and temporal regulation of GLUT4 translocation by flotillin-1 and caveolin-3 in skeletal muscle cells. FASEB J. 20, 705-707. 
Frick, M., Bright, N.A., Riento, K., Bray, A., Merrified, C., Nichols, B.J., 2007. Coassembly of flotillins induces formation of membrane microdomains, membrane curvature, and vesicle budding. Curr. Biol. 17, 1151-1156.

Gagescu, R., Demaurex, N., Parton, R.G., Hunziker, W., Huber, L.A., Gruenberg, J., 2000. The recycling endosome of Madin-Darby canine kidney cells is a mildly acidic compartment rich in raft components. Mol. Biol. Cell 11, 2775-2791.

Gkantiragas, I., Brugger, B., Stuven, E., Kaloyanova, D., Li, X.Y., Lohr, K., Lottspeich, F., Wieland, F.T., Helms, J.B., 2001. Sphingomyelin-enriched microdomains at the Golgi complex. Mol. Biol. Cell 12, 1819-1833.

Glebov, O.O., Bright, N.A., Nichols, B.J., 2006. Flotillin-1 defines a clathrin-independent endocytic pathway in mammalian cells. Nat. Cell Biol. 8, 46-54.

Huang, K., El-Husseini, A., 2005. Modulation of neuronal protein trafficking and function by palmitoylation. Curr. Opin. Neurobiol. 15, 527-535.

Huang, K., Yanai, A., Kang, R., Arstikaitis, P., Singaraja, R.R., Metzler, M., Mullard, A., Haigh, B., GauthierCampbell, C., Gutekunst, C.A., Hayden, M.R., El-Husseini, A., 2004. Huntingtin-interacting protein HIP14 is a palmitoyl transferase involved in palmitoylation and trafficking of multiple neuronal proteins. Neuron 44, 977-986.

Keller, C.A., Yuan, X., Panzanelli, P., Martin, M.L., Alldred, M., Sassoe-Pognetto, M., Luscher, B., 2004. The gamma2 subunit of GABA(A) receptors is a substrate for palmitoylation by GODZ. J. Neurosci. 24, 5881-5891.

Kimura, A., Baumann, C.A., Chiang, S.H., Saltiel, A.R., 2001. The sorbin homology domain: a motif for the targeting of proteins to lipid rafts. Proc. Natl. Acad. Sci. USA 98, 9098-9103.

Lang, D.M., Lommel, S., Jung, M., Ankerhold, R., Petrausch, B., Laessing, U., Wiechers, M.F., Plattner, H., Stuermer, C.A., 1998. Identification of reggie-1 and reggie-2 as plasmamembrane-associated proteins which cocluster with activated GPI-anchored cell adhesion molecules in noncaveolar micropatches in neurons. J. Neurobiol. 37, 502-523.

Langhorst, M.F., Reuter, A., Stuermer, C.A., 2005. Scaffolding microdomains and beyond: the function of reggie/ flotillin proteins. Cell. Mol. Life Sci. 62, 2228-2240.

Langhorst, M.F., Genisyuerek, S., Stuermer, C.A., 2006 a. Accumulation of FlAsH/Lumio Green in active mitochondria can be reversed by beta-mercaptoethanol for specific staining of tetracysteine-tagged proteins. Histochem. Cell Biol. 125, 743-747.

Langhorst, M.F., Reuter, A., Luxenhofer, G., Boneberg, E.M., Legler, D.F., Plattner, H., Stuermer, C.A., 2006b. Preformed reggie/flotillin caps: stable priming platforms for macrodomain assembly in T cells. FASEB J. 20, 711-713.

Langhorst, M.F., Solis, G.P., Hannbeck, S., Plattner, H., Stuermer, C.A., 2007. Linking membrane microdomains to the cytoskeleton: regulation of the lateral mobility of reggie-1/flotillin-2 by interaction with actin. FEBS Lett. 581, 4697-4703.

Legler, D.F., Doucey, M.A., Schneider, P., Chapatte, L., Bender, F.C., Bron, C., 2005. Differential insertion of GPI- anchored GFPs into lipid rafts of live cells. FASEB J. 19, 73-75.

Le Roy, C., Wrana, J.L., 2005. Clathrin- and non-clathrinmediated endocytic regulation of cell signalling. Nat. Rev. Mol. Cell Biol. 6, 112-126.

Li, R., Liu, T., Yoshihiro, F., Tary-Lehmann, M., Obrenovich, M., Kuekrek, H., Kang, S.C., Pan, T., Wong, B.S., Medof, M.E., Sy, M.S., 2003. On the same cell type GPI-anchored normal cellular prion and DAF protein exhibit different biological properties. Biochem. Biophys. Res. Commun. 303, 446-451.

Liu, P., Ying, Y., Zhao, Y., Mundy, D.I., Zhu, M., Anderson, R.G., 2004. Chinese hamster ovary K2 cell lipid droplets appear to be metabolic organelles involved in membrane traffic. J. Biol. Chem. 279, 3787-3792.

Madore, N., Smith, K.L., Graham, C.H., Jen, A., Brady, K., Hall, S., Morris, R., 1999. Functionally different GPI proteins are organized in different domains on the neuronal surface. EMBO J. 18, 6917-6926.

Martin, T.F., Grishanin, R.N., 2003. PC12 cells as a model for studies of regulated secretion in neuronal and endocrine cells. Meth. Cell Biol. 71, 267-286.

Morrow, I.C., Rea, S., Martin, S., Prior, I.A., Prohaska, R., Hancock, J.F., James, D.E., Parton, R.G., 2002. Flotillin-1/ reggie-2 traffics to surface raft domains via a novel Golgiindependent pathway. Identification of a novel membrane targeting domain and a role for palmitoylation. J. Biol. Chem. 277, 48834-48841.

Nebenfuhr, A., Ritzenthaler, C., Robinson, D.G., 2002. Brefeldin A: deciphering an enigmatic inhibitor of secretion. Plant Physiol. 130, 1102-1108.

Neumann-Giesen, C., Falkenbach, B., Beicht, P., Claasen, S., Luers, G., Stuermer, C.A., Herzog, V., Tikkanen, R., 2004. Membrane and raft association of reggie-1/flotillin-2: role of myristoylation, palmitoylation and oligomerization and induction of filopodia by overexpression. Biochem. J. 378, 509-518.

Neumann-Giesen, C., Fernow, I., Amaddii, M., Tikkanen, R., 2007. Role of EGF-induced tyrosine phosphorylation of reggie-1/flotillin-2 in cell spreading and signaling to the actin cytoskeleton. J. Cell Sci. 120, 395-406.

Nichols, B.J., 2002. A distinct class of endosome mediates clathrin-independent endocytosis to the Golgi complex. Nat. Cell Biol. 4, 374-378.

Payne, C.K., Jones, S.A., Chen, C., Zhuang, X., 2007. Internalization and trafficking of cell surface proteoglycans and proteoglycan-binding ligands. Traffic 8, 389-401.

Pelkmans, L., Zerial, M., 2005. Kinase-regulated quantal assemblies and kiss-and-run recycling of caveolae. Nature 436, 128-133.

Peters, P.J., Mironov Jr., A., Peretz, D., van Donselaar, E., Leclerc, E., Erpel, S., DeArmond, S.J., Burton, D.R., Williamson, R.A., Vey, M., Prusiner, S.B., 2003. Trafficking of prion proteins through a caveolae-mediated endosomal pathway. J. Cell Biol. 162, 703-717.

Plattner, H., Zingsheim, H.P., 1983. Electron microscopic methods in cellular and molecular biology. Subcell. Biochem. 9, 1-236.

Prado, M.A., Alves-Silva, J., Magalhaes, A.C., Prado, V.F., Linden, R., Martins, V.R., Brentani, R.R., 2004. PrPc on 
the road: trafficking of the cellular prion protein. J. Neurochem. 88, 769-781.

Reuter, A., Binkle, U., Stuermer, C.A., Plattner, H., 2004. $\operatorname{PrP}(\mathrm{c})$ and reggies/flotillins are contained in and released via lipid-rich vesicles in Jurkat T cells. Cell. Mol. Life Sci. 61, 2092-2099.

Rivera-Milla, E., Stuermer, C.A., Malaga-Trillo, E., 2006. Ancient origin of reggie (flotillin), reggie-like, and other lipid-raft proteins: convergent evolution of the SPFH domain. Cell. Mol. Life Sci. 63, 343-357.

Rocks, O., Peyker, A., Kahms, M., Verveer, P.J., Koerner, C., Lumbierres, M., Kuhlmann, J., Waldmann, H., Wittinghofer, A., Bastiaens, P.I., 2005. An acylation cycle regulates localization and activity of palmitoylated Ras isoforms. Science 307, 1746-1752.

Royle, S.J., Murrell-Lagnado, R.D., 2003. Constitutive cycling: a general mechanism to regulate cell surface proteins. BioEssays 25, 39-46.

Schroeder, W.T., Stewart-Galetka, S., Mandavilli, S., Parry, D.A., Goldsmith, L., Duvic, M., 1994. Cloning and characterization of a novel epidermal cell surface antigen (ESA). J. Biol. Chem. 269, 19983-19991.

Schulte, T., Paschke, K.A., Laessing, U., Lottspeich, F., Stuermer, C.A., 1997. Reggie-1 and reggie-2, two cell surface proteins expressed by retinal ganglion cells during axon regeneration. Development 124, 577-587.

Shyng, S.L., Heuser, J.E., Harris, D.A., 1994. A glycolipidanchored prion protein is endocytosed via clathrin-coated pits. J. Cell Biol. 125, 1239-1250.
Solis, G.P., Hoegg, M., Munderloh, C., Schrock, Y., MalagaTrillo, E., Rivera-Milla, E., Stuermer, C.A., 2007. Reggie/ flotillin proteins are organized into stable tetramers in membrane microdomains. Biochem. J. 403, 313-322.

Solomon, S., Masilamani, M., Rajendran, L., Bastmeyer, M., Stuermer, C.A., Illges, H., 2002. The lipid raft microdomain-associated protein reggie-1/flotillin-2 is expressed in human B cells and localized at the plasma membrane and centrosome in PBMCs. Immunobiology 205, 108-119.

Stuermer, C.A., Lang, D.M., Kirsch, F., Wiechers, M., Deininger, S.O., Plattner, H., 2001. Glycosylphosphatidyl inositol-anchored proteins and fyn kinase assemble in noncaveolar plasma membrane microdomains defined by reggie-1 and -2. Mol. Biol. Cell 12, 3031-3045.

Stuermer, C.A., Langhorst, M.F., Wiechers, M.F., Legler, D.F., Hannbeck von Hanwehr, S., Guse, A.H., Plattner, H., 2004. PrPc capping in T cells promotes its association with the lipid raft proteins reggie-1 and reggie-2 and leads to signal transduction. FASEB J. 18, 1731-1733.

Sunyach, C., Jen, A., Deng, J., Fitzgerald, K.T., Frobert, Y., Grassi, J., McCaffrey, M.W., Morris, R., 2003. The mechanism of internalization of glycosylphosphatidylinositol-anchored prion protein. EMBO J. 22, 3591-3601.

Tavernarakis, N., Driscoll, M., Kyrpides, N.C., 1999. The SPFH domain: implicated in regulating targeted protein turnover in stomatins and other membrane-associated proteins. Trends Biochem. Sci. 24, 425-427. 